\title{
MING GAP AND THE REVIVAL OF COMMERCIAL PRODUCTION OF BLUE AND WHITE PORCELAIN IN CHINA
}

\author{
Yew Seng Tai
}

School of Archaeology and Museology, Peking University, Beijing City, China; taiyewseng@gmail.com

\begin{abstract}
This paper listed the blue and white porcelains excavated with date inscriptions or from datable tombs in China and shows that there was a 'Ming Gap' of blue and white porcelain in China too. Previously, Ming Gap was thought to be restricted to Southeast Asia. This author argues that no blue and white porcelain was allowed to produce in commercial kilns in early Ming Dynasty. But, when the needed raw material, cobalt--which relied on trade in the time of Ming Ban--could be produced locally, the commercial production of blue and white porcelain restarted.
\end{abstract}

\section{INTRODUCTION}

This paper discusses the reasons for the shortage of commercial blue and white porcelain and the revival of its production in Ming China. The materials used in this paper are excavated from datable tombs or possess date inscriptions. There is an adequate amount of material for both analysis and pinpointing a precise date for the re-emergence of blue and white porcelain. Because of this, the large number of blue and white porcelains from hoards, ancient city sites, and shipwrecks excavated in China that lack such temporal precision are not included in this paper.

While the number of blue and white wares excavated in China is sufficient for systematic analysis, little research has been done on this topic, in contrast to research on export wares, where much attention has been drawn to the Ming Gap.

\section{MING GAP}

The term 'Ming Gap' was first used by Tom Harrisson (1958:273-277). He mentioned that sites spanning over 100 miles along the southwest Borneo coast had no sign of human activity during Ming dynasty, not even the broken porcelain that is normal for that period.
Roxanna Brown (2004:xi-xii) confirmed the existence of Ming Gap in her PhD dissertation. She listed 15 shipwrecks with Chinese and Southeast Asia ceramics in the region and identified two types of shortages. The first is a general shortage of Chinese ceramic during 1325-1380. The second is a specific severe shortage of blue and white porcelain, which she called the Ming Gap, during 1352-1487. She has proven that China had $100 \%$ share of ceramic market before 1325 , but the market share decreased to $50 \%$ from 1368 to 1424-1430 (Hongwu reign and Zheng He voyages), and further decreased to $5 \%$ from $1424-1430$ to 1487 . It rebounded from 1488 to 1505 (Hongzhi reign) and decreased again for the next 60 years. China regained monopoly in ceramic trade after 1573 .

\section{COMPARISON OF SHIPWRECK AND DATABLE TOMB CERAMICS}

To explain the reasons of shortages, we need to examine the information on blue and white porcelains in China during these periods. Table 1 lists Yuan and Ming blue and white porcelains with date inscriptions, along with those from datable tombs. It does not includes heirlooms, items brought from the markets, items excavated without date inscription, items not from datable tombs, or items with obvious characteristics of the previous era which fail to correspond to their burial date. Those items not included are listed on Tables 4 through 6 . The latter tables require special attention, because they are properly excavated items discovered in datable tombs, but considered Yuan products by researchers. On Table 1, after the blue and white dish of 1353, there is a time span of 84 years before the next commercial blue and white porcelain appears in 1437. The incense burner in Table 4 has an earlier date of 1351. It is not included due to the colour of its glaze. The David Vases in the Percival David Foundation collection are two other blue and white wares with dates of 1351. They are not included in this analysis, since we are focusing on items excavated in China. 
BULLETIN OF THE INDO-PACIFIC PREHISTORY ASSOCIATION 31, 2011

\begin{tabular}{|c|c|c|c|c|c|}
\hline Year & Location & Unearthed from & Item (Inscription) & Qty & Ref \\
\hline 1353 & Suixi, Anhui & Tomb of Sun & Dish & 1 & $\begin{array}{l}\text { (Wang et al. } \\
\text { 2009:37) }\end{array}$ \\
\hline 1437 & Xinjiang, Jiangxi & $\begin{array}{l}\text { Tomb of Zhu Pan Shi, eld- } \\
\text { est son of Prince Ningxian }\end{array}$ & Jar with lid & 5 & $\begin{array}{l}\text { (Ku et al. 1973: 64- } \\
66,54)\end{array}$ \\
\hline 1442 & Nanjing, Jiangsu & Base of Hongjue Temple & Jar with lid & 5 & (Cai 1956:73) \\
\hline 1447 & Dexing, Jiangxi & Tomb of Zhang Shuwei & $\begin{array}{l}\text { Vase } \\
\text { Incense Burner }\end{array}$ & $\begin{array}{l}2 \\
1\end{array}$ & (Sun 2000:295-298) \\
\hline 1448 & Taichang, Jiangsu & Tombs of Mr \& Mrs Chai & Jar with lid & 2 & $\begin{array}{l}\text { (Xu et al. 1993: 52- } \\
54,32)\end{array}$ \\
\hline 1451 & Dexing, Jiangxi & Tomb of Zhang & $\begin{array}{l}\text { Vase } \\
\text { Tripod incense burner }\end{array}$ & $\begin{array}{l}2 \\
1\end{array}$ & (Sun 2000:295-298) \\
\hline 1453 & Jingdezhen, Jiangxi & Tomb of Yan Sheng & $\begin{array}{l}\text { Vase } \\
\text { Incense burner } \\
\text { Dish } \\
\text { Bowl }\end{array}$ & $\begin{array}{l}4 \\
1 \\
1 \\
1\end{array}$ & $\begin{array}{l}\text { (Ouyang et al. } \\
\text { 1981:46-50) }\end{array}$ \\
\hline 1456 & Jingdezhen, Jiangxi & $\begin{array}{l}\text { Tomb of Mdm Yuan } \\
\text { Longzhen }\end{array}$ & $\begin{array}{l}\text { Dish } \\
\text { Bowl } \\
\text { Vase } \\
\text { Incense burner }\end{array}$ & $\begin{array}{l}1 \\
2 \\
2 \\
2\end{array}$ & $\begin{array}{l}\text { (Ouyang et al. } \\
\text { 1981:46-50) }\end{array}$ \\
\hline $\begin{array}{l}1457- \\
1464\end{array}$ & Jingdezhen, Jiangxi & Hutian kiln site & $\begin{array}{l}\text { Bowl (Made in the reign } \\
\text { of Tianshun, Great Ming } \\
\text { dynasty) }\end{array}$ & 1 & $\begin{array}{l}\text { (Liu et al. 1980:39- } \\
49 \text { ) }\end{array}$ \\
\hline 1459 & $\begin{array}{l}\text { Dongguan, Guang- } \\
\text { dong }\end{array}$ & Tomb of Luo Hengxin & Jar with lid & 5 & $\begin{array}{l}\text { (Guangdong Provin- } \\
\text { cial Museum et al. } \\
\text { 1991:43-50) }\end{array}$ \\
\hline 1464 & Pingwu, Sichuan & $\begin{array}{l}\text { Tombs of Mr \& Mrs Wang } \\
\mathrm{Xi}\end{array}$ & $\begin{array}{l}\text { Washer } \\
\text { Plate } \\
\text { Bowl }\end{array}$ & $\begin{array}{c}1 \\
67 \\
1\end{array}$ & $\begin{array}{l}\text { (CPAM Sichuan } \\
\text { Province et al. } \\
\text { 1987:1-42) }\end{array}$ \\
\hline 1467 & Boyang, Jiangxi & - & Jar with lid & 2 & (Yang 1983:85-95) \\
\hline 1467 & Yongxiu, Jiangxi & $\begin{array}{l}\text { Tomb of Mdm Lu (Wife of } \\
\text { Minister of Defense Wei } \\
\text { Yuan) }\end{array}$ & Bowl & 2 & $\begin{array}{l}\text { (Jiangxi Provincial } \\
\text { Museum 1973:286- } \\
\text { 289) }\end{array}$ \\
\hline 1480 & Linchuan, Jiangxi & - & Tripot incense burner & 1 & $\begin{array}{l}\text { (Ku et al. 1973: 64- } \\
66,54)\end{array}$ \\
\hline 1484 & Qingjiang, Jiangxi & A tomb & $\begin{array}{l}\text { Incense burner (Written } \\
\text { with ink: Brought by } \\
\text { Jiang Huanbi when pass- } \\
\text { ing Jingdezhen on 1st } \\
\text { day of } 7 \text { th month, 20th } \\
\text { year of the Chenghua } \\
\text { reign[22nd July 1484]) }\end{array}$ & 1 & (Huang 1984:24) \\
\hline
\end{tabular}

Table 1. Yuan and Ming blue and white porcelains with date inscriptions or from datable tombs (13521487). Porcelains dated later are excluded. They are out of the time frame of Ming Gap. 


\begin{tabular}{|l|l|l|l|}
\hline Dated & Country & Shipwreck & Ceramic and Quantity \\
\hline $\begin{array}{l}\text { Yuan Dyn- } \\
\text { asty }\end{array}$ & Unknown & Red Sea & 19 blue and white porcelains \\
\hline $\begin{array}{l}\text { Yuan Dyn- } \\
\text { asty }\end{array}$ & $\begin{array}{l}\text { Shandong, } \\
\text { China }\end{array}$ & Heze & 3 blue and white porcelains \\
\hline 1370 & Malaysia & Turiang & $\begin{array}{l}6475 \text { pieces of ceramics, including 2400 pieces made in China, } \\
\text { mainly Longquan wares and jars from other southern China kilns }\end{array}$ \\
\hline 1380 & Malaysia & Nanyang & $\begin{array}{l}\text { Investigation: 402 Thai samples, estimated up to10,000 pieces, } \\
\text { including Jars made in China }\end{array}$ \\
\hline 1400 & Malaysia & Longquan & $\begin{array}{l}10,000 \text { pieces of ceramics, 40\% made in China, mainly celadons } \\
\text { from Longquan and white wares from southern China }\end{array}$ \\
\hline 1460 & Malaysia & Royal Nanhai & $\begin{array}{l}20,973 \text { pieces of ceramics, including } 6 \text { blue and white wares and } 1 \\
\text { celadon made in China }\end{array}$ \\
\hline $1436-1464$ & Philippine & Pandanan & $\begin{array}{l}75 \text { pieces of blue and white porcelains in 4722 items, 75\% of it are } \\
\text { made in Vietnam }\end{array}$ \\
\hline 1490 & Philippine & Lena Shoal & 3000 blue and white porcelains \\
\hline 1490 & Philippine & Santa Cruz & 11,500 pieces of ceramics \\
\hline
\end{tabular}

Table 2. Shipwreck ceramics from Yuan to Ming (1490). Shipwrecks dating later are excluded. They are out of the time frame of Ming Gap.

\begin{tabular}{|l|l|l|l|}
\hline Time Period & Year & Description & Reference \\
\hline $\begin{array}{l}\text { 3rd year of the } \\
\text { Zhengtong } \\
\text { reign }\end{array}$ & 1439 & $\begin{array}{l}\text { On the Bingyin day of 12th month, 3rd year of the Zhengtong reign } \\
\text { (1st Jan 1439), (the emperor) ordered the Duchayuan to post the } \\
\text { notice of banning the production, selling and presenting to officer as } \\
\text { gift of naval blue on white ground porcelain in the kilns of Jiangxi. } \\
\text { Offender will be sentenced to death and the family will be banished } \\
\text { to a frontier post. }\end{array}$ & $\begin{array}{l}\text { Ming Yingzong } \\
\text { Shilu, Vol. 49 }\end{array}$ \\
\hline $\begin{array}{l}\text { 9th month, } \\
\text { 12th year of } \\
\text { the Zhengtong } \\
\text { reign }\end{array}$ & 1447 & $\begin{array}{l}\text { The soldiers and businessmen of the post stations and towns along } \\
\text { the roads of Northern and Southern Capitals, Shanxi, Henan, Hu- } \\
\text { guang, Gansu, Datong and Liaodong, are not allowed to sell naval } \\
\text { blue on white ground wares to foreign emissaries. }\end{array}$ & $\begin{array}{l}\text { Ming Yingzong } \\
\text { Shilu, Vol.161 }\end{array}$ \\
\hline $\begin{array}{l}\text { 12th year of } \\
\text { the Zhengtong } \\
\text { reign }\end{array}$ & 1448 & $\begin{array}{l}\text { On the Jiaxu day of 12th month, 12th year of the Zhengtong reign } \\
\text { (22nd Jan 1448), (the emperor) banned the private production of } \\
\text { yellow, purple, pink, green, naval blue, light blue and naval blue on } \\
\text { white ground (now blue and white) coloured ceramics in Raozhou } \\
\text { (now Jingdezhen), Jiangxi. (The emperor) ordered the office of Ducha- } \\
\text { yuan to post notice there. Offender will be sentenced to death by the } \\
\text { slow process of slicing, property will be confiscated and male family } \\
\text { member will be sent to a frontier post as soldier. Those failed to re- } \\
\text { port this offence will be prosecuted too. }\end{array}$ & $\begin{array}{l}\text { Ming Yingzong } \\
\text { Shilu, Vol.161 }\end{array}$ \\
\hline
\end{tabular}

Table 3. Banning orders of coloured ceramics. 
BULLETIN OF THE INDO-PACIFIC PREHISTORY ASSOCIATION 31, 2011

\begin{tabular}{|c|c|c|c|c|c|}
\hline Year & Location & From & Characteristic (Date inscription) & Qty & Reference \\
\hline 1319 & Jiujiang, Jiangxi & $\begin{array}{l}\text { Datable } \\
\text { tomb }\end{array}$ & $\begin{array}{l}\text { Jar with pagoda lid [Applied qingbai monster } \\
\text { mask] }\end{array}$ & 1 & $\begin{array}{l}\text { (Jiujiang Munici- } \\
\text { pal Museum } \\
\text { 1981:83) }\end{array}$ \\
\hline 1338 & $\begin{array}{l}\text { Fengcheng, } \\
\text { Jiangxi }\end{array}$ & $\begin{array}{l}\text { Datable } \\
\text { tomb of } \\
\text { Mdm Ling }\end{array}$ & $\begin{array}{l}\text { Figures [Qingbai ware, underglaze copper red] } \\
\text { Jar with pagoda lid (Offering on the renyin day of } \\
\text { the 6th month of wuyin year, the Great Yuan } \\
\text { dynasty; used by Mdm Ling of Liu family)[Qingbai } \\
\text { ware, underglaze copper red, inscription written } \\
\text { in cobalt blue] } \\
\text { Granary [Qingbai ware, underglaze copper red, } \\
\text { epitaph written in cobalt blue] }\end{array}$ & 2 & $\begin{array}{l}\text { (Yang et al. } \\
\text { 1981:72-74) }\end{array}$ \\
\hline 1347 & Yaan, Sicuan & & $\begin{array}{l}\text { Jar with lid (Offering in 7th year of the Zhizheng } \\
\text { reign)[Qingbai ware] }\end{array}$ & 1 & (Li 1988:79) \\
\hline 1351 & Guangji, Hubei & $\begin{array}{l}\text { Tomb of } \\
\text { Mdm Shu }\end{array}$ & $\begin{array}{l}\text { Incense burner (11th year of the Zhizheng reign) } \\
\text { [Qingbai glaze] }\end{array}$ & 1 & ( Wu 1992:45-95) \\
\hline 1351 & London & PDF & $\begin{array}{l}\text { David Vases (In Jitang Commune of Dejiao Nei- } \\
\text { bourhood, Shuncheng Village of Yushan Prefec- } \\
\text { ture, Xinzhou, devotee Zhang Wen Jin offered an } \\
\text { incense burner and a pair of vases, wishing the } \\
\text { family purified and the children healthy. On the } \\
\text { first day of 4th month, 11th year of the Zhizheng } \\
\text { reign (26th April 1351). Presented with all respect } \\
\text { to General Hu Jingyi in Xingyuan Zudian Temple.) }\end{array}$ & 2 & \\
\hline
\end{tabular}

Table 4. Yuan dynasty blue and white porcelain with date inscription. The reasons they are not listed in Table 1 are given in square brackets.

\begin{tabular}{|l|l|l|c|}
\hline Year & Related Location & Characteristic (Date inscription) & Qty \\
\hline 1437 & $\begin{array}{l}\text { 1986 in Hong Kong / The } \\
\text { Art Institute of Chicago }\end{array}$ & $\begin{array}{l}\text { Vase(Devotee Cheng Jin offered on 1st day of 1st month, } \\
\text { second year of the Zhengtong reign (5th Feb 1437)) }\end{array}$ & 1 \\
\hline 1443 & $\begin{array}{l}\text { Guangdong Provincial Mu- } \\
\text { seum }\end{array}$ & $\begin{array}{l}\text { Brush rack (8th year of the Zhengtong reign (31st Jan } \\
\text { 1443-19th Jan 1444)) }\end{array}$ & 1 \\
\hline 1450 & Ji'an, Jiangxi & $\begin{array}{l}\text { Tablet (21st day of 6th month, 1st year of the Jingtai reign } \\
\text { (29th July 1450)) }\end{array}$ & 1 \\
\hline 1451 & Sotheby's, London & Jar & 1 \\
\hline 1461 & Hong Kong Museum of Art & Vase & 1 \\
\hline 1463 & Taiyuan, Shanxi & $\begin{array}{l}\text { Incense burner (Ma in Datong, 7th year of the Tianshun } \\
\text { reign / Written by Ma in Datong, 7th year of the Tianshun } \\
\text { reign (20th Jan 1463-6th Feb 1464)) }\end{array}$ & 1 \\
\hline $1457-1464$ & Palace Museum, Beijing & $\begin{array}{l}\text { Incense burner (Tianshun reign [26th Jan 1457-26th Jan } \\
1465])\end{array}$ & 1 \\
\hline
\end{tabular}

Table 5. Ming dynasty blue and white porcelain with inscription. This group is not included in the primary analysis because excavation reports are unavailable. This does not affect the paper's conclusions. Items dated later are not included. They are out of the time frame of Ming Gap. 
TAI: MING GAP AND THE REVIVAL OF COMMERCIAL PRODUCTION OF BLUE AND WHITE PORCELAIN

\begin{tabular}{|l|l|l|l|l|l|}
\hline $\begin{array}{l}\text { Year of } \\
\text { burial }\end{array}$ & Location & Owner & $\begin{array}{l}\text { Item Inscription } \\
\text { [Date suggested] }\end{array}$ & Qty & Reference \\
\hline 1371 & $\begin{array}{l}\text { Jiangning,Na } \\
\text { njing }\end{array}$ & Marquis Wang Xingzu & $\begin{array}{l}\text { Stem cup } \\
\text { [Late Yuan dynasty] }\end{array}$ & $\begin{array}{l}\text { (Nanjing Munici- } \\
\text { pal Museum } \\
1972: 31-33, \text { plate } \\
6 \text { and 7) }\end{array}$ \\
\hline 1389 & $\begin{array}{l}\text { Jiangning,Na } \\
\text { njing }\end{array}$ & Duchess Yu Tonghai & $\begin{array}{l}\text { Shards of Meiping vase } \\
\text { [Zhizheng type }\end{array}$ & $\begin{array}{l}\text { (Nanjing Munici- } \\
\text { pal Museum et al. } \\
1999: 18-26, \text { plate } \\
3 \text { ) }\end{array}$ \\
\hline 1392 & $\begin{array}{l}\text { Jiangning,Na } \\
\text { njing }\end{array}$ & Prince of Qianning, Mu Ying & $\begin{array}{l}\text { Meiping vase } \\
\text { [Zhizheng type] }\end{array}$ & 1 & $\begin{array}{l}\text { (Anonymous } \\
1951: 101-128)\end{array}$ \\
\hline 1395 & $\begin{array}{l}\text { Anhui } \\
1410\end{array}$ & Prince of Dongou, Tang He & $\begin{array}{l}\text { Jar with lid } \\
\text { [Yuan] }\end{array}$ & $\begin{array}{l}\text { (Museum of the } \\
\text { City of Pengpu } \\
1977: 35-39, \text { plate } \\
\text { 4) }\end{array}$ \\
\hline 1418 & $\begin{array}{l}\text { Nanjing } \\
\text { zhaishan, } \\
\text { Nanjing }\end{array}$ & Lady Ye & $\begin{array}{l}\text { Meiping vase } \\
\text { (Four four) [Yuan (Cheng } \\
2000: 130-136)]\end{array}$ & 1 & $\begin{array}{l}\text { (Nanjing Munici- } \\
\text { pal Museum } \\
1997: 29-32)\end{array}$ \\
\hline
\end{tabular}

Table 6. Ming blue and white from datable tomb with characteristics of Yuan wares.

Nevertheless, the time span is not affected. It shows that there was a time gap of blue and white porcelain in China too. This is corresponding to the Ming gap of shipwrecks ceramic, shown in the Table 2.

According to Table 2, Royal Nanhai (1460) had 7 Chinese wares including 6 blue and white porcelains. This was followed by Pandanan, with about 70 interregnum (1436 -1464) blue and white wares. 30 years after the Royal Nanhai, a ship with blue and white cargo sunk in Philippine waters. The Lena Shoal carried about 3000 pieces of blue and white porcelains. Goddio believes these goods were heading for Turkey or Persia (Goddio et al. 2000:11). This shipwreck data shows that there was an increase in the momentum of trade after blue and white porcelain exports restarted. Comparing Table 2 with Table 1, the blue and white in China and Southeast Asia have corresponding time gap. This raised a question: if the Ming gap was the result of Ming ban, the shortage of Chinese porcelain should be in Southeast Asia but not China. Why did the disappearance and re-emergence of blue and white porcelain in China correspond to similar phenomena among the wares in Southeast Asian shipwrecks?

\section{REASONS FOR THE MING GAP}

From 1352 to 1487 , a series of incidents interrupted the production of Chinese ceramics. Rebels led by Xiang Pushou attacked Jingdezhen in1352. It changed hands several times and eventually fell under the control of Zhu Yuanzhang in 1361 (Xi 1873:875, 877). The porcelain production department of the Yuan dynasty, 'Fuliang Ciju' (Porcelain Bureau of Fuliang - now Jingdezhen), probably stopped its operation during this time (Liu, 1982:18). The David Vases (1351) from the Percival David Foundation, the incense burner (1351) and the dish from the Tomb of Sun (1353) mentioned above were probably the last batch of blue and white porcelain produced before the war. Zhu Yuanzhang founded the Ming dynasty in 1368 and reunited China in 1387. He banned private voyage. Although his successor, Zhu Di, send Zheng He overseas to establish missions, they were different from commercial endeavors. The qualities, quantities, types and distribution of ceramics were unavoidably affected. Furthermore, some of the emperors did not enforce the Ming ban, which resulted in surges of ceramic exports during the ban.

Perhaps, another important factor is the Ming court's attitude towards porcelain, which was different from that of the Song and Yuan dynasties. The Ming dynasty set up the imperial kiln in Jingdezhen to produce the ceramics for the imperial court. Unselected porcelains were smashed and buried in the compound of the Zhuashan kiln site in Jingdezhen (Quan 2005:54-63) so they would not enter the market. The Southern Song (1127-1279) imperial kilns had 
handled some of their unselected ceramics the same way (Qin 2005:64-79), but only limited themselves to imperial ritual wares, which they considered sacred. Whether or not there was imperial kiln in Yuan dynasty is unknown, but potters in Jingdezhen were working for the Porcelain Bureau of Fuliang (now Jingdezhen). They were allowed to sell their products after they had fulfilled their duties, as were the other artisans in Yuan dynasty. (Franke 1994:654) The methods of producing the new variant of porcelain (the blue and white wares) had proliferated. The Ming dynasty wanted to stop it, though the reasons for this may not have been economic; the presence of blue and white wares in Ming tombs, as seen on Table 6, demonstrates that they may have been awarded as honours to the generals who helped to found the empire. Conversely, they may have played a role as ritual wares in said generals' funerals. If the blue and white wares were freely available, it defeats the purpose.

In the early stage of blue and white porcelain production, during Yuan dynasty, the cobalt used for underglaze painting was imported, the potters worked for the 'Porcelain Bureau' (Fuliang Ciju), and the designers were probably court artists (Liu 1982:9-20). The imperial government controlled most of the important factors of the production: the imported materials, the designs and the labourers. When the resources were unavailable, commercial kilns were not able to produce this ware. The breakthrough probably occurred in the Xuande reign (1426-1435). According to the analysis of the cobalt on the fragments excavated from the imperial kiln sites, the Hongwu (1368-1398) and Yongle (1403-1424) blue and white porcelains used imported cobalt, which contains high amount of iron and low level of manganese. On the other hand, the fragments from Xuande stratum used local cobalt, which contains low level of iron and high level of manganese (Li 1996:163-167). This implies that, from the Xuande reign, blue and white porcelain production did not depend on imported cobalt. If one of the most important materials for producing blue and white porcelain could be obtained locally, commercial potters would be able to restart the production. When said production sprang up like mushrooms in the early Zhengtong (1436-1449) reign, the emperor ordered the banning of coloured ceramics, like those on Table 3.

There are two important dates on Tables 2 and 3. The first is the second year of the Zhengtong reign, which marked the re-appearance of blue and white porcelain. The second date is the third year of the Zhengtong reign (1439), which according to Yingzong Shilu, is the year blue and white porcelain was banned. This shows that the imperial court tried to stop the commercial production of blue and white porcelain. Ten years later, the court reiterated the order, which shows that the commercial production of blue and white porcelain was unstoppable; by 1490, it had developed into a major export product, as we can see from ceramics recovered in the Lena Shoal shipwreck.
By virtue of the banning of coloured wares in 1438 , commercial kilns were not allow to produce yellow, purple, pink, green, navy blue, light blue, and 'blue-on-white-ground' wares. They were only allowed to produce white ware, brown ware, black ware and celadon. If this is so, the discoveries of Turiang (1370-1400) and Longquan (1424-1440) are significant. Longquan contained an estimated 40,000 pieces of Chinese ceramics ( $40 \%$ of the cargo), mainly Longquan celadons and southern China white wares. On board the Turiang, $35 \%$ of the cargo is Chinese ceramics, mainly Guangdong wares (green-glazed, brown-glazed and monochrome) and Longquan celadons. Their cargos reflect the types of ceramics allowed to produce in China commercial kilns during that period.

One thing to take note of is the severe punishment for producing and selling blue and white porcelains and coloured wares. Although the Ming dynasty had one of the toughest laws in Chinese history, the 4th emperor Ren Zong (13781425) banned the cruel punishment of slicing to death, unless the sovereignty of the emperor is challenged. That such a punishment was applied to the potters who produced coloured wares shows that these wares were considered sacred at this period of time. They may have been designed to be used in the imperial rituals, presented to the generals, and as gifts to the foreign states, as it was banned to sell blue and white porcelains to foreigners (Table 3 ).

\section{CONCLUSION}

By comparing the blue and white porcelains excavated with date inscriptions and dates from tombs, we learn that there was a gap in the production of this porcelain in China from 1354 to 1436 . While it began with the eruption of war, it did not end with the establishment of the new Ming Empire, but was instead prolonged through the order to ban coloured wares production by commercial kilns. The Ming ban probably made it difficult for the skilled potters, already freed from the Porcelain Bureau, to get the needed imported raw material. But when they were provided with locally produced cobalt, the commercial production of blue and white porcelain restarted.

Given the background of Ming Ban, it seems easy to make the connection between it and the Ming Gap. This study has proven that it is not the case. The nature of Ming Ban was not to ban trading, but to control pirating. To some extent, it did allow local Chinese traders to trade with the representatives of the heads of foreign states in China, and foreign traders to trade with the representatives of Chinese emperors overseas. This is a way to stamp out piracy. If blue and white ware production was allowed in commercial kilns of China for export, there will be some traces of it in overseas. Nonetheless the ban made trading more difficult, and may have caused some of the Chinese potters to set up their workshops overseas to circumvent the policy. 


\section{REFERENCES}

Anonymous. 1951. Investigation Report of Ancient Relics in Nanjing and Surrounding Areas. Cultural Relics References (Wenwu Cankao Ziliao) 7: 101-128. (In Chinese)

Brown, R.M. 2004. The Ming Gap and Shipwreck Ceramics in Southeast Asia. Unpublished Ph.D. dissertation, University of California, Los Angeles.

Cai, S. 1956. Relics Discovered in a Pagoda of Hongjue Buddhist Monastery in Niushoushan, Nanjing. Culture Relics Reference (Wenwu Cankao Ziliao) 11: 73. (In Chinese)

Cheng, X. 2000. A Study of Meiping from Ming Aristocrat Tombs in Nanjing. China Ancient Ceramics Studies 6: 130-136. (In Chinese)

CPAM Sichuan Province, Cultural Centre of the City of Mianyang and CPAM Pingwu County. 1987. Tombs of Wang Xi's Family of the Ming Dynasty at Pingwu, Sichuan. Wenwu (Cultural Relics) 7: 1-42. (In Chinese)

Franke, H. and D. Twitchett. 1994. The Cambridge History of China, Vol 6: Alien Regimes and Border States, 9071368. New York: Cambridge University Press.

Feng, B. 1959. Ming Tombs Discovered in Xigucheng Village, Anci County. Cultural Relics 1: 71. (In Chinese)

Goddio F., S. Pierson, and M. Crick. 2000. Sunken Treasure: Fifteenth Century Chinese Ceramics from the Lena Cargo. London: Periplus.

Guangdong Provincial Museum and Museum of the City of Dongguan. 1991. Excavation of the Ming Tombs of Luo Hengxin Family in Dongguan, Guangdong. Wenwu (Cultural Relics) 11:43-50. (In Chinese)

Harrisson, T. 1958. 'Ming Gap' and Kota Batu, Brunei (with appeal for help). The Sarawak Museum Journal New Series 8(11)/Old Series (26): 273-77.

Huang, Y. 1984. Blue and White Incense Burner with Design of Scrolling Flora, Chenghua reign, Ming Dynasty. Wenwu (Cultural Relics) 3: 24. (In Chinese)

Jiangxi Provincial Museum. 1973. Ming tombs of Yushan, Linchuan and Yongxiu Counties, Jiangxi. Kaogu (Archaeology) 5: 286-289. (In Chinese)

Jiujiang Municipal Museum. 1981. Blue and White Porcelain Vase with Peony Design and Pagoda on Lid. Wenwu (Cultural Relics) 1: 83. (In Chinese)
Ku, H. and P. Chen. 1973. Some Blue and White Porcelains of the Yuan and Ming Dynasties. Wen Wu (Cultural Relics) 12: 64-66, 54. (In Chinese)

Li, J. and Z. Zhang, Z. Deng, X. Liu. 1996. A Study of the Techniques of Yuan and Early Ming Blue and White Porcelain Imperial Wares. Chang Foundation Museum Bulletin 1: 163-167. (In Chinese)

Li, Z. 1988. Hoard of Yuan Dynasty Porcelain Discovered in Yaan City. Sichuan Cultural Relics (Sichuan Wenwu) 5: 79. (In Chinese)

Liu, X. and K. Bai. 1980. Reconnaissance of Ancient Kiln Sites at Hutian in Jingdezhen. Wen Wu (Cultural Relics) 11: 39-49. (In Chinese)

Liu, X. 1982. Research on the Yuan Blue-and-white Wares with Unique Patterns Decoration, Fouliang Porcelain Bureau and Huaju Bureau. Journal of Jingdezhen Ceramic Institute 3: 9-20. (In Chinese)

Museum of the City of Pengpu. 1977. Excavation of the Ming Dynasty Tomb of T'ang Ho. Wen Wu (Cultural Relics) 2: 35-39, plate 4. (In Chinese)

Nanjing Municipal Museum. 1972. Preliminary Excavation Report of Ming Tomb of Wang Xingzu in Nanjing. Kaogu (Archaeology) 4: 31-33, plate 6 and 7. (In Chinese)

Nanjing Municipal Museum. 1997. Preliminary Excavation Report of Ming Tombs in Southern Suburb of Nanjing. Relics from the South 1: 29-32. (In Chinese)

Nanjing Municipal Museum, Yuhuatai Culture and Cultural Relics Bureau. 1999. Preliminary Excavation Report of Ming Tombs in Qijiashan, Nanjing City, Jiangsu. Kaogu (Archaeology) 10: 18-26, plate 3. (In Chinese)

Ouyang, S. and Y. Huang. 1981. The Underglazed Red Porcelains and the Blue and White Unearthed in the Tombs of the Reign of Ming Emperor Jing Tai. Wen $W u$ (Cultural Relics) 2: 46-50. (In Chinese)

Quan, K. 2005. On the Arrangement of Royal Porcelain Failing Selection in the Ming and Qing Dynasties. Cultural Relics 5: 54-63. (In Chinese)

Qin, D. 2005. Production and Producers of the Ritual Ceramics in the Song Dynasty. Cultural Relics 5: 64-79. (In Chinese)

Sun, Y. 2000. Research on Blue and White Porcelain from Datable Tombs of Zhengtong and Jingtai Reign of Ming 
Dynasty in Dexing, Jiangxi. China Ancient Ceramic Studies (Zhongguo Gu Taoci Yanjiu) 6: 295-298. (In Chinese)

Wang, D. and J. Bian. 2009. Porcelain Treasures in Yuan Dynasty. Beijing: Wenwu Publishing. (In Chinese)

Wang, N. and X. Shen. 2000. Brief Description of Ming Dynasty Interregnum Blue and White Porcelain with Date Inscription. China Ancient Ceramic Studies (Zhongguo Gu Taoci Yanjiu) 6: 282-289. (In Chinese)

Wu, S. 1992. Blue and White discovered in Jiujiang, Jiangxi. Cultural Relics 6: 45-95. (In Chinese)

Xi, De and Shi, Jingfen. 1873. Raozhou Fuzhi. (Local Gazetteer of Raozhou Prefecture) Taipei: Chengwen Chubanshe. (In Chinese)

$\mathrm{Xu}$, Y., R. Ren and J. Jiang. 1993. Analyzing Some Decorative Features of Blue-and-White Porcelain's Designs During Zhengtong, Jingtai and Tianshun Period of Ming Dynasty. Jingdezhen's Ceramic 59-60(Spring Summer): 52-54, 32. (In Chinese)

Yang, H. 1983. Blue and White Porcelain Unearthed from Datable Tombs of Ming Dynasty in Jiangxi. Jiangxi History and Cultural Relics (Jiangxi Lishi Wenwu) 3: 85 -95. (In Chinese)

Yang, H. and L. Wan. 1981. Underglazed Red, Blue and White Porcelain with Date Inscription of Yuan Dynasty Discovered in Fengcheng, Jiangxi. Wenwu (Cultural Relics) 11: 72-74. (In Chinese)

Zhang, B. 2008. Complete Collection of Ceramic Art Unearthed in China 7 Jiangsu. Beijing: Science Press. (In Chinese) 